\title{
KAJIAN SINEMATOGRAFI FILM PENDEK “JAKARTA LOCKDOWN" OLEH CAMEO PROJECT
}

\author{
Shirly Novian Wulandari ${ }^{1)}$, Nurusshofi Mariyyah ${ }^{2)}$ \\ Program Studi Desain Komunikasi Visual, \\ Fakultas Bahasa dan Seni, Universitas Indraprasta PGRI \\ Jl. Nangka No. 58 C, Tanjung Barat, Jakarta Selatan, 12530, Indonesia
}

Email: shirly.novian@gmail.com

\begin{abstract}
Abstrak
Pada awal 2020, pandemi virus corona (Covid-19) telah menggoncangkan umat manusia diseluruh dunia. Dalam menghadapi penyebaran virus corona ke seluruh penjuru dunia, membuat pemerintah melakukan reaksi cepat sosialisasi pencegahan terhadap masyarakat. Pemerintah berinisiatif untuk melakukan kebijakan lockdown selama beberapa waktu yang ditentukan guna mengantisipasi penularan wabah virus corona. Oleh karena itu penelitian ini bertujuan untuk menganalisa film pendek "Jakarta Lockdown (SHORT MOVIE) \#DiRumahAja \#SamaSaya" yang diproduksi oleh Cameo Project guna menumbuhkan kesadaran masyarakat dalam menghadapi virus corona. Penelitian ini menggunakan pendekatan kualitatif yang mengacu pada metode prinsip angle dan shot sinematografi. Hasil penelitian menyatakan bahwa kebijakan pemerintah pada saat ini memberikan pengaruh kepada masyarakat. Terlihat warga di Indonesia yang mata pencahariannya sebagai para pekerja mengalami kehilangan penghasilan mereka dan masyarakat Indonesia mengalami kekhawatiran yang berlebihan terhadap virus corona, sehingga masyarakat menimbun bahan-bahan pokok untuk kehidupan sehari-hari selama masa pandemi. Karena pemerintah harus memfasilitasi segala kebutuhan masyarakat selama kebijakan lockdown diterapkan oleh pemerintah.
\end{abstract}

Kata Kunci: virus corona, Lockdown, Angle, Shot, dan Sinematografi.

\begin{abstract}
In the early 2020s, the virus corona pandemic (Covid-19) has shaken humanity around the world. In dealing with the spread of virus corona to all corners of the world, the government made a quick reaction to prevention socialization to the community. The government took the initiative to carry out a lockdown policy for a certain amount of time to anticipate the transmission of the virus corona outbreak. Therefore, this study aims to analyze the short film "Jakarta Lockdown (SHORT MOVIE) \#OntheHouse \#SameMe" produced by the Cameo Project to raise public awareness in dealing with the virus corona. This study uses a qualitative approach that refers to the principal method of angle and shot cinematography. The results of the study stated that current government policies had an influence on society. It can be seen that people in Indonesia whose livelihoods as workers have lost their income and the Indonesian people are experiencing excessive concern about the virus corona, so that the community is hoarding basic ingredients for daily life during the pandemic. Because the government must facilitate all the needs of the community as long as the lockdown policy is implemented by the government.
\end{abstract}

Keywords: virus corona, Lockdown, Angle, Shot, and Cinematography.

Correspondence author: Shirly Novian Wulandari, shirly.novian@gmail.com, Jakarta, and Indonesia 


\section{PENDAHULUAN}

Sejak awal ditetapkannya wabah virus corona (Covid-19) ini sebagai masa pandemi, pemerintah selalu memberikan arahan, aturan, perintah, dan larangan kepada warga negaranya agar tetap patuh dan turut andil agar bisa memutus rantai penyebaran virus tersebut. Virus corona (Covid-19) adalah sekumpulan virus dari subfamily Orthocronavirinae dalam keluarga Coronaviridae dan Ordo Nidovirales. Kelompok virus ini dapat menyebabkan penyakit pada burung dan mamalia, termasuk manusia. Pada manusia, virus corona menyebabkan infeksi saluran pernapasan yang umumnya ringan seperti pilek, meskipun beberapa bentuk penyakit seperti; SARS (severe acute respiratory syndrome), MERS (Middle East Respiratory Syndrome), dan COVID-19 (virus corona) yang sifatnya lebih mematikan. Virus ini bukanlah suatu wabah yang bisa diabaikan begitu saja, karena orang awam akan mengira bahwa gejala awalnya seperti influenza biasa, tetapi bagi analisis kedokteran virus ini cukup berbahaya dan mematikan (Yunus $\&$ Rezki, 2020).

Virus corona yang berhubungan dengan SARS bisa saja muncul sebagai mutan dari virus corona manusia yang memperoleh faktor virulensi baru, sebagai mutan dari virus corona hewan yang dapat menginfeksi sel manusia, atau sebagai rekombinan dari dua virus corona manusia atau virus corona manusia dan virus corona hewan. Antibodi terhadap virus corona terkait SARS ditemukan dalam sampel serum yang diperoleh dari pasien dengan SARS selama masa pemulihan tetapi tidak dalam sampel serum manusia yang disimpan sebelum KLB SARS, menunjukkan bahwa virus corona yang terkait dengan SARS adalah baru bagi populasi manusia (Holmes, 2003).

Diketahui, virus tersebut berasal dari kota Wuhan di China yang diduga terdapat pasar tradisional yang menjual daging hewan dan makanan laut. Banyak peneliti menduga bahwa virus corona berasal dari hewan kelelawar dan kemungkinan kelelawar telah menginfeksi ayam hidup maupun hewan lainnya yang dijual di pasar tersebut. Pasar tersebut menyebabkan resiko penularan virus hewan ke manusia dengan cepat. Karena kualitas standar kebersihan pasar yang masih dikatakan sangat jorok, serta penyembelihan hewan juga dilakukan di lokasi kejadian (Mujib, 2020).

Kondisi saat ini semakin buruk dengan kondisi lingkungan yang tidak sehat menyebabkan beberapa penyakit infeksi akut yang berbahaya menyerang manusia seperti penyakit yang bersumber pada binatang seperti leptospirosis (Tarigan, 2020). Leptospirosis merupakan penyakit yang disebabkan oleh infeksi bakteri yang bergerak aktif menyerang hewan dan manusia. Penyakit tersebut secara alami dapat dipindahkan dari hewan ke manusia atau sebaliknya.

Virus corona menyerang saluran pernapasan manusia. Seseorang dapat terinfeksi dari penderita virus corona. Penyakit ini dapat menyebar melalui tetesan kecil (droplet) dari hidung atau mulut pada saat batuk atau bersin. Droplet tersebut kemudian jatuh pada benda di sekitarnya. Kemudian jika orang lain menyentuh benda yang sudah terkontaminasi dengan droplet tersebut, lalu orang itu menyentuh mata, hidung atau mulut (segitiga wajah), maka orang itu dapat terinfeksi virus corona. Bisa juga seseorang terinfeksi virus corona ketika tanpa sengaja menghirup droplet dari penderita (Indrawati, 2020).

Akibat dari adanya pandemi virus corona ini memberikan pengaruh hampir pada seluruh aspek kehidupan masyarakat. Mengantisipasi dan mengurangi jumlah penderita virus corona, pemerintah Indonesia memberikan kebijakan social distancing dan membatasi aktivitas keluar rumah. Konsep ini menjelaskan bahwa untuk dapat mengurangi bahkan memutus mata rantai infeksi virus corona, seseorang harus menjaga jarak aman dengan manusia lainnya minimal 2 meter, dan tidak melakukan kontak langsung dengan orang lain, menghindari pertemuan massal (Buana, 2020).

Terkait aktivitas yang dirumahkan sudah menjadi kebijakan dalam kondisi khususnya yang harus dilakukan. Hampir seluruh kegiatan dirumahkan, dan kebijakan ini disebut dengan Lockdown. Lockdown dapat membantu mencegah penyebaran virus ke suatu tempat yang ada di wilayah tertentu, sehingga masyarakat yang berada di suatu tempat tersebut diharapkan dapat terhindar dari penyebaran virus tersebut. Dampak dari adanya kebijakan lockdown ini adalah 
melemahnya aktivitas kegiatan ekonomi yang dilakukan masyarakat. Menjalarnya virus corona di Indonesia telah menimbulkan fenomena kepanikan di tengah masyarakat yang menyebabkan orang-orang melakukan panic buying, sehingga orang-orang memborong banyak barang. Dan hal tersebut akan mengganggu kelancaran distribusi barang dan jasa, karena melakukan belanja yang berlebihan untuk menimbun bahan makanan dan barang kebutuhan sehari-hari.

Penyakit penyebaran virus corona (Covid-19) ini perlu disosialisasikan melalui film pendek. Studi ini tentang kajian film pendek "Jakarta Lockdown (SHORT MOVIE) \#DiRumahAja \#SamaSaya" yang diproduksi oleh Cameo Project. Istilah film awalnya dimaksudkan untuk menyebut media penyimpan gambar atau biasa disebut Celluloid, yaitu lembaran plastik yang dilapisi oleh lapisan kimiawi peka cahaya. Menurut buku yang berjudul " 5 Hari Mahir Membuat Film" (Javandalasta, 2011: 1) dijelaskan bahwa film adalah rangkaian gambar yang bergerak membentuk suatu cerita atau juga bisa disebut Movie atau Video (Ali, 2013).

Jadi, film biasa dipakai untuk merekam suatu keadaan atau mengemukakan sesuatu. Film dipakai untuk memenuhi suatu kebutuhan umum, yaitu mengkomunikasikan suatu gagasan, pesan atau kenyataan. Karena keunikan dimensinya, film telah diterima sebagai salah satu media audio visual yang paling popular dan digemari. Selain itu film juga dianggap sebagai media yang paling efektif (Syafrudin \& Pujiyono, 2013).

Film pendek adalah film dengan durasi pendek antara 1 menit -2 menit, menurut standar film internasional. Mengenai cara bertuturnya, film pendek memberikan kebebasan bagi para pembuat sehingga bentuknya menjadi sangat bervariasi. Film pendek dapat saja hanya berdurasi 60 detik, yang penting ide dan pemanfaatan media komunikasinya dapat berlangsung efektif (Setiono \& Riwinoto, 2015).

Tujuan kajian ini untuk menumbuhkan kesadaran dan menjauhkan stigma masyarakat yang mempercayai bahwa penyebaran virus corona merupakan suatu hal yang tidak bisa dianggap enteng, serta memutus rantai penyebaran dengan cara individual yang dapat berpengaruh terhadap lingkungan sekitar. Stigma tergambar dari ketakutan yang berlebihan, sikap sinis, keras kepala, dan berpikir negatif pada masyarakat sekitar. Banyak yang beranggapan bahwa berita kasus penyebaran virus corona tersebut merupakan suatu hal yang hanya membuatnya menjadi takut keluar rumah. Hal ini menyebabkan tidak terpenuhinya kebutuhan untuk hidup sehari-hari hingga seluruh masyarakat menjadi bosan dan kehilangan pekerjaan.

\section{METODE PENELITIAN}

Penelitian ini menggunakan pendekatan kualitatif yang mengacu pada metode prinsip angle sinematografi. Penelitian kualitatif yaitu penelitian yang dilakukan dengan peraturan tertentu yang ada di dalam kehidupan riil (alamiah) dengan tujuan menginvestigasi dan memahami fenomena: apa yang terjadi, mengapa terjadi dan bagaimana terjadinya. Riset kualitatif ialah berbasis pada konsep "akan menjelajahi" yang melibatkan studi mendalam dan berorientasi kasus dalam sejumlah kasus atau kasus tunggal. Tujuan utama penelitian kualitatif yaitu membuat fakta mudah dipahami dan jika memungkinan (sesuai modelnya) dapat menghasilkan hipotesis baru (Chariri, 2009). Mengacu pada metode prinsip angle dan shot sinematografi, sinematografi adalah kata serapan dari bahasa Inggris Cinematography yang berasal dari bahasa Latin kinema 'gambar'. Sinemtografi sebagai ilmu terapan merupakan bidang ilmu yang membahas tentang teknik menangkap gambar dan menggabung-gabungkan gambar tersebut sehingga menjadi rangkaian gambar yang dapat menyampaikan ide (dapat mengemban cerita) (Maahury et al., 2015).

Sinematografi menjelaskan tentang pengoperasian kamera dengan baik serta cara pemeliharaanya, proses perekaman yang dapat menghasilkan gambar dan suara dengan baik, dan mengasah inisiatif untuk menyesuaikan diri dengan baik, dan mengasah inisiatif untuk menyesuaikan diri dengan keterbatasan alat (Ali, 2013).

Kajian tentang film pendek "Jakarta Lockdown (SHORT MOVIE) \#DiRumahAja \#SamaSaya" yang diproduksi oleh Cameo Project ini dapat dilihat melalui sudut teknik pengambilan gambar tiap scene yang berpatokan pada prinsip angle dan shot sinematografi guna mengetahui tipe apa saja yang dipakai pada film pendek tersebut. Angle adalah sudut pengambilan 
gambar. Istilah angle ini berlaku baik dalam pengambilan gambar atau video. Penentuan angle secara tepat akan menghasilkan shot yang baik. Angle dapat mempengaruhi emosi dan psikologi penonton, karena shot yang dihasilkan bersifat obyektif, subyektif, atau merupakan sudut pandang tokoh dalam film. Sedangkan shot merupakan sudut pengambilan gambar yang mendefinisikan suatu rangkaian gambar hasil rekaman kamera tanpa interupsi (Angga W \& Abdillah, 2017).

\section{HASIL DAN PEMBAHASAN}

Cameo Project merupakan kumpulan orang-orang kreatif yang berbasis di Jakarta. Cameo Project terbentuk pada tahun 2008 dan menampilkan konten-konten yang tidak hanya bertujuan untuk menghibur tetapi juga menginspirasi banyak orang serta memberikan pengaruh positif untuk penikmat karya mereka. Kelompok yang konsisten berkarya di dunia video online ini beranggotakan Reza Nangin, Martin Anugrah, iBob Tarigan, Steve Pattinama, Andry Ganda, dan Yosi Mokalu.

Seluruh dunia sedang menghadapi situasi genting yang diakibatkan oleh penyebaran virus corona (Covid-19). Film pendek yang berjudul "Jakarta Lockdown" diproduksi oleh Cameo Project sebagai bentuk kampanye virus corona, diharapkan film pendek ini dapat mengedukasi dan menyadarkan masyarakat luas akan pentingnya menjaga kebersihan, kesehatan, dan yang terpenting agar masyarakat dapat menerapkan program pemerintah yaitu lockdown atau tetap stay di rumah jika tidak ada kepentingan yang benar-benar mendesak.

Film ini menceritakan bagaimana Martin, Reza \& Ibob yang harus bertahan dalam situasi lockdown. Mereka bertahan dengan persediaan makanan yang mulai menipis, contohnya beras. Mereka adalah tipe pemuda yang pemalas namun beras di rumah sudah habis. Karena mereka mulai kelaparan, Reza pun akhirnya dengan terpaksa keluar rumah untuk membeli beras, namun ia tidak mengikuti prosedur kesehatan seperti menggunakan masker saat keluar rumah. Akhirnya salah seorang pemuda menegur dan memberinya masker, vitamin dan hand sanitizer secara gratis. Setelah Reza pulang ke rumah ternyata temannya, Ibob, mati karena kelaparan. Sedangkan Martin yang sedang asyik makan mie dengan santainya bilang bahwa "Suruh makan mie nggak mau, enak padahal". Akhirnya tiba-tiba Reza tidak sengaja batuk di depan Martin yang sedang makan mie.

Film pendek "Jakarta Lockdown" oleh Cameo Project memiliki sudut teknik pengambilan gambar yang berbeda tiap scene. Berikut adalah beberapa jenis angle dan shot yang terdapat pada film pendek tersebut.

\section{Bird Eye View}

Bird Eye atau mata burung merupakan salah satu teknik pengambilan gambar yang dilakukan juru kamera dengan ketinggian kamera di atas ketinggian objek yang diambil. Hasil pengambilan teknik ini memperlihatkan lingkungan yang demikian luas dengan benda-benda lain yang tampak di bawah demikian kecil dan berserakan tanpa mempunyai makna (Laksana, 2013).

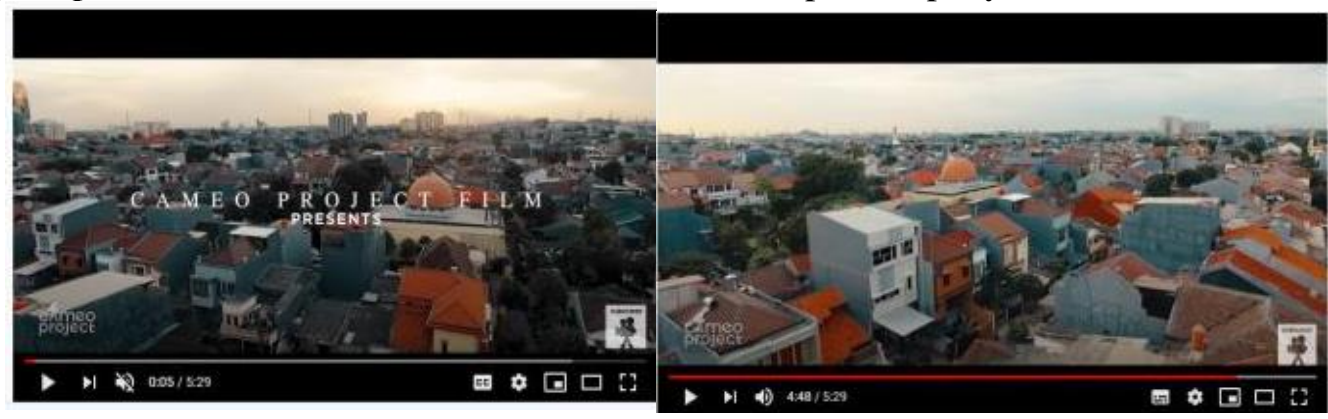

Gambar 1 Menit ke 0:05

Gambar 2 Menit ke 4:48

Pada scene di atas langit terlihat berwarna orange kegelapan, menunjukkan suasana sore hari dari sudut atas kota Jakarta yang padat penduduk. Pengambilan gambar tersebut menggunakan drone, sehingga dapat memperlihatkan pemandangan kota secara luas. 


\section{High Angle}

High Angle merupakan sudut pengambilan dari atas objek sehingga kesan objek jadi mengecil. Selain itu teknik pengambilan gambar ini mempunyai kesan dramatis, yaitu nilai 'kerdil' (Laksana, 2013).

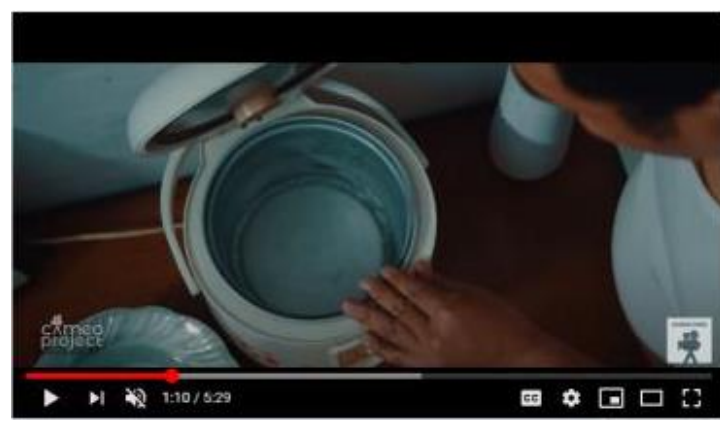

Gambar 3 Menit ke 1:10

Pada scene ini menampilkan sudut pandang yang diambil dari atas kepala pria. Ia terlihat sedang membuka rice cooker yang kosong atau tidak ada nasinya, seakan-akan menunjukan bahwa ia sedang kelaparan dan berusaha mencari sesuatu di dalam wadah tersebut.

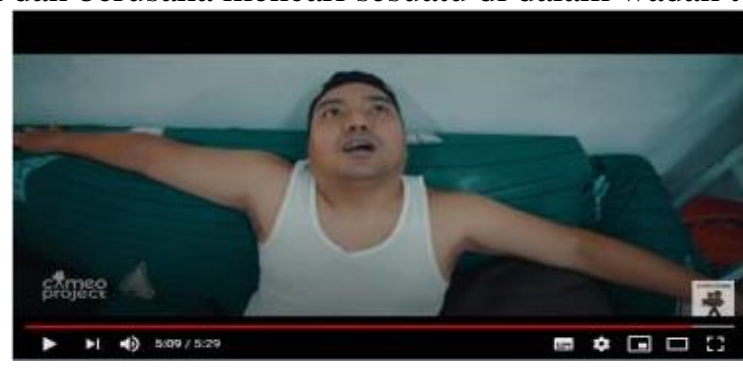

Gambar 4 Menit ke 5:09

Pada scene ini menampilkan sudut pandang yang diambil dari atas. Terlihat objek (pria bersinglet) sedang terkapar mati karena kelaparan. Ia tidak kuat menahan rasa lapar dan menunggu temannya yang sedang membeli beras.

\section{Wide / Long Shot}

Long Shot adalah teknik pengambilan gambar yang memperlihatkan seluruh tubuh dari batas kepala hingga kaki. Pengambilan gambar dari jarak yang cukup jauh sehingga dapat memperlihatkan objek dan latar belakangnya. Long Shot akan memberikan informasi secara lengkap mengenai suasana dari adegan atau interaksi antara tokoh yang satu dengan tokoh yang lainnya (Ginanjar Angga W \& Abdillah, 2017).

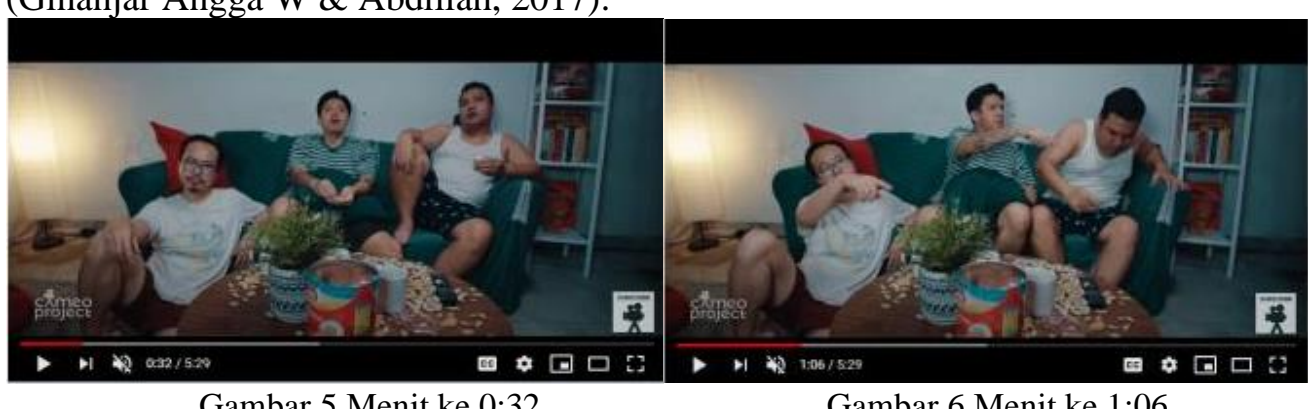

Gambar 5 Menit ke 0:32

Gambar 6 Menit ke 1:06

Pada scene ini seluruh objek (tiga orang pria) masuk ke dalam frame, dan menunjukkan kegiatan seperti sedang asyik duduk sambil menonton berita di televisi. Adegan pada gambar pertama memperlihatkan ketiga pria sedang membicarakan topik berita di televisi, dan adegan pada gambar kedua memperlihatkan ketiga pria sedang merasa kelaparan. 


\section{Two Shot}

Two Shot adalah pengambilan gambar yang menampilkan dua objek yang terlibat percakapan (Sandy \& Sya'dian, 2020).

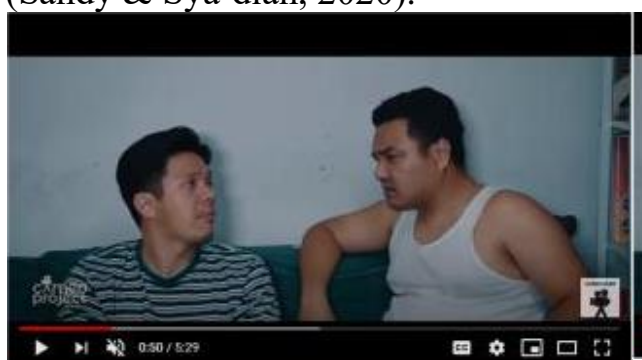

Gambar 7 Menit ke 0:50



Gambar 8 Menit ke 1:02

Pada scene ini menampilkan pria yang memakai kaos dalam atau singlet yang sedang berbincang dengan pria berbaju hijau garis-garis. Dua pria tersebut sedang berdebat untuk memilih siapa yang harus keluar rumah membeli beras. Perdebatan tersebut terlihat dari ekspresi yang sinis dan gerakan tangan yang sedang menggenggam dengan erat.

\section{Eye Level}

Eye Level artinya, sudut pengambilan gambar sejajar dengan objek. Eye Level ini memang tidak memberikan kesan dramatis karena dalam kondisi shot biasa-biasa saja. Hasilnya memperlihatkan tangkapan pandangan mata seseorang yang berdiri atau pandangan mata seseorang yang mempunyai ketinggian tubuh tepat tingginya sama dengan objek (Laksana, 2013).

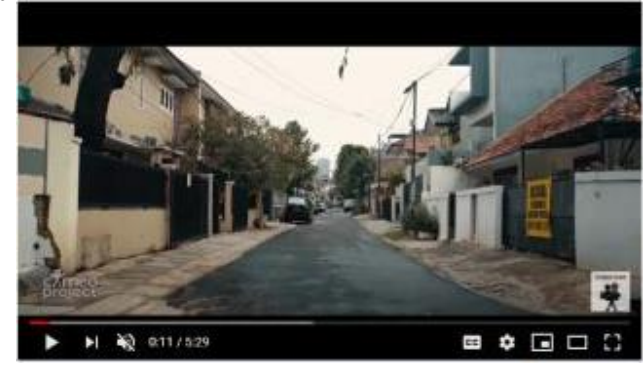

Gambar 9 Menit ke 0:11

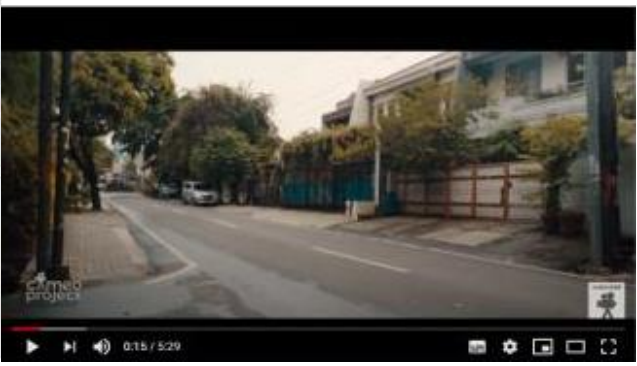

Gambar 10 Menit ke 0:15

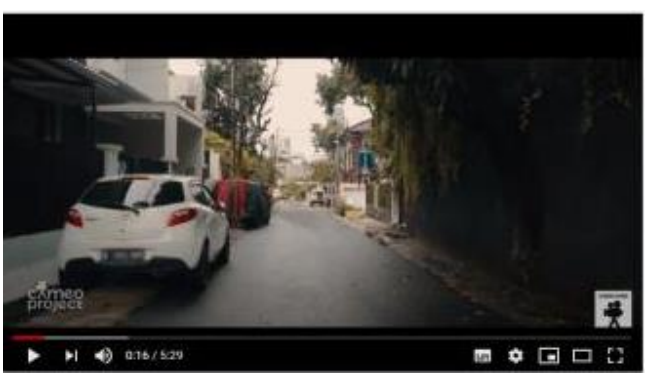

Gambar 11 Menit ke 0:16

Menunjukkan bahwa walaupun Jakarta adalah kota yang padat penduduk namun ternyata suasananya berbeda, sepi dan tidak ada orang yang keluar. Memperlihatkan tangkapan pandangan mata seseorang yang berdiri atau pandangan mata seseorang yang mempunyai ketinggian tubuh tepat tingginya sama dengan objek.

\section{MCU (Medium Close Up)}

Medium Close Up merupakan teknik pengambilan gambar yang memperlihatkan objek dari ujung kepala hingga dada. Shot ini baik untuk seseorang yang sedang berbicara langsung di 
depan kamera. Kesan yang akan ditimbulkan adalah objek akan terfokus, sedangkan background tidak terfokus, dengan demikian akan menonjolkan objek (Ginanjar Angga W \& Abdillah, 2017).

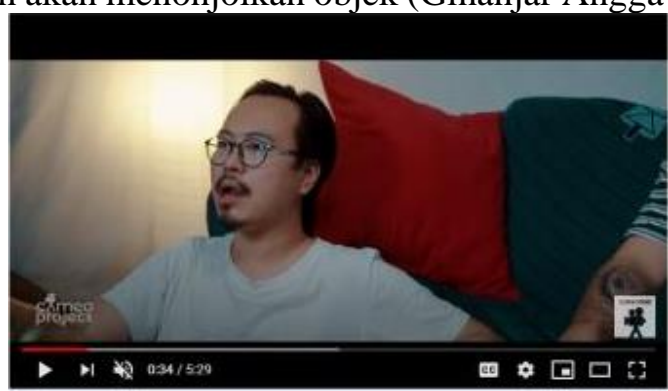

Gambar 12 Menit ke 0:34

Menampilkan pria berkacamata dan berbaju putih sedang membuka percakapan atau diskusi tentang berita virus corona di televisi yang terlihat dari pantulan sinar di kacamatanya. Terdapat pengambilan gambar yang memperlihatkan objek dari ujung kepala hingga dada.

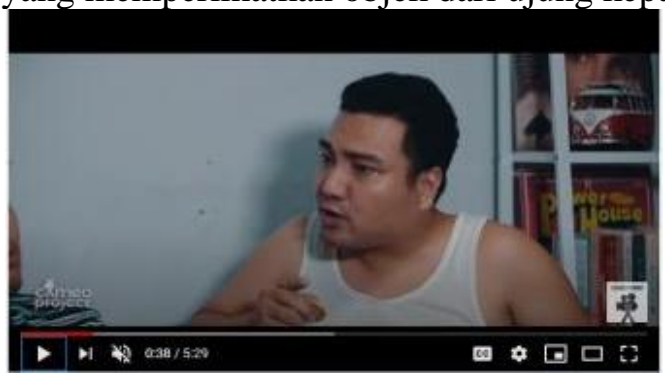

Gambar 13 Menit ke 0:38

Menunjukkan pria yang memakai kaos dalam atau singlet yang sedang membalas percakapan dari pria berbaju putih. Terdapat pengambilan gambar yang memperlihatkan objek dari ujung kepala hingga dada.



Gambar 14 Menit ke 2:45

Menampilkan lebih dekat ekspresi pria berbaju hijau yang terkejut melihat seorang perempuan memiliki mata yang berbeda dari manusia pada umumnya. Terdapat pengambilan gambar yang memperlihatkan objek dari ujung kepala hingga dada.

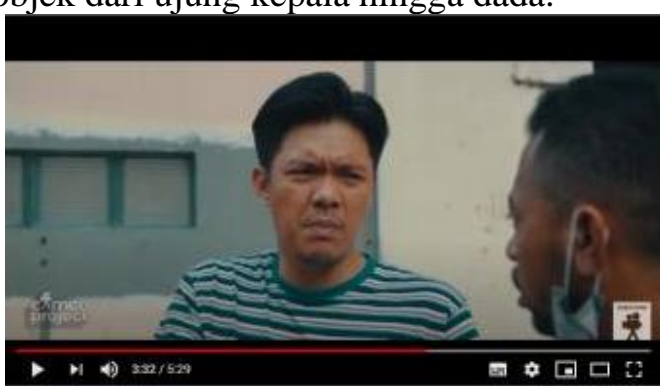

Gambar 15 Menit ke 3:32 
Menampilkan lebih dekat ekspresi pria berbaju hijau yang sedang bingung mendengarkan himbauan dari pria berjaket biru. Terdapat pengambilan gambar yang memperlihatkan objek dari ujung kepala hingga dada.

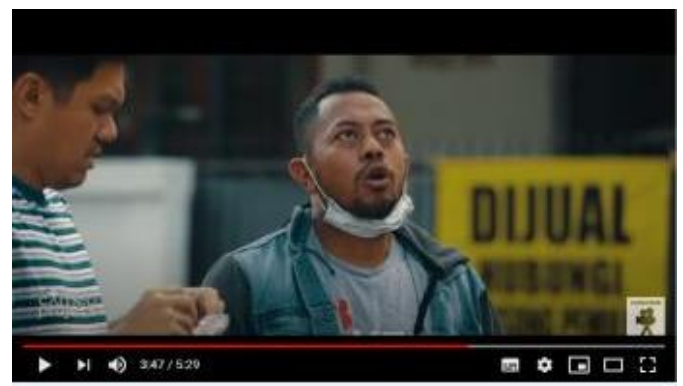

Gambar 16 Menit ke 3:47

Terdapat pengambilan gambar dari ujung kepala hingga dada. Memperlihatkan pria berjaket biru sedang menjelaskan anjuran untuk minum vitamin kepada pria berbaju hijau garisgaris yang sedang membuka kemasan vitamin tersebut.

\section{MS (Medium Shot)}

Medium Shot adalah pengambilan gambar atas kepala hingga pinggang/perut bagian bawah, fungsinya untuk memperlihatkan sosok objek secara jelas. Ada keseimbangan antara dominasi objek dengan background sehingga cenderung netral (Ginanjar Angga W \& Abdillah, 2017).

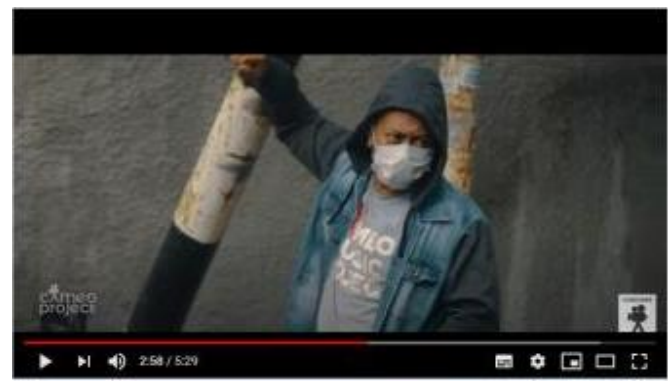

Gambar 17 Menit ke 2:58

Pada scene ini terdapat pria berjaket biru yang sedang bertumpu pada plang komplek. Pria tersebut sedang memperhatikan pria berbaju hijau garis-garis yang keluar rumah tanpa memakai masker. Menampilkan pengambilan gambar dari atas kepala hingga pinggang atau perut bagian bawah.



Gambar 18 Menit ke 3:39

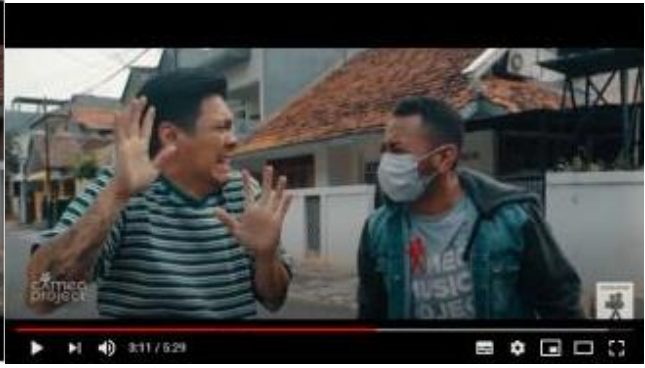

Gambar 19 Menit ke 3:1

Pada scene ini terdapat interaksi pria berjaket biru yang sedang menghimbau pria berbaju hijau garis-garis untuk memakai masker jika keluar rumah. Menampilkan pengambilan gambar dari atas kepala hingga pinggang atau perut bagian bawah. 


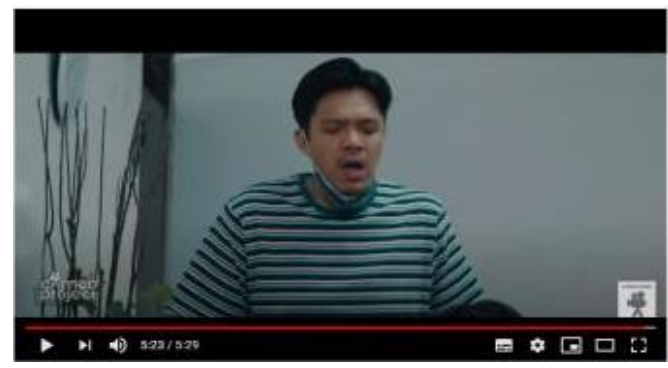

Gambar 20 Menit ke 5:23

Pada scene ini adalah scene terakhir dimana terdapat ekspresi pria berbaju hijau garisgaris yang sedang batuk dihadapan temannya yang sedang makan mie di meja makan. Menampilkan pengambilan gambar dari atas kepala hingga pinggang atau perut bagian bawah.

\section{KS (Knee Shot)}

Knee Shot, yaitu pengambilan gambar dari atas kepala hingga lutut. Batasan framing Knee Shot adalah 3/4 ukuran tubuh manusia (Ginanjar Angga W \& Abdillah, 2017).

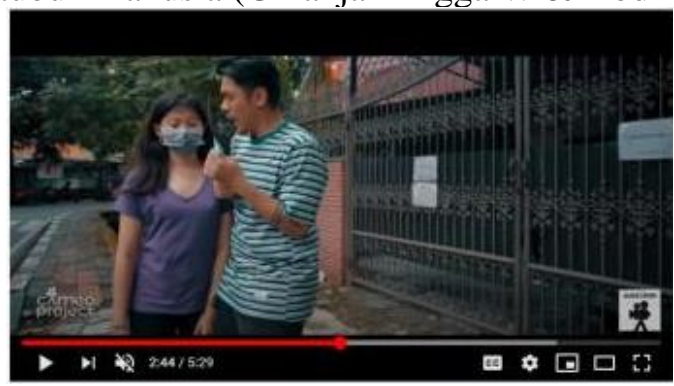

Gambar 21 Menit ke 2:44

Pada scene ini pria berbaju hijau tidak sengaja menabrak perempuan yang memakai masker dan baju berwarna ungu dihadapannya. Pengambilan gambar memperlihatkan objek dari kepala hingga lutut.

\section{ECU (Extreme Close Up)}

Extreme Close Up memperlihatkan detail suatu objek dalam jarak yang sangat dekat (mata, hidung, mulut, jari). Biasanya digunakan untuk menunjukan benda atau aktivitas yang penting pada penonton. Jenis shot ini berguna memusatkan perhatian audiens terhadap deatail suatu objek. Biasanya memakai lensa makro dalam penggunaannya (Tamamuddin, 2017).

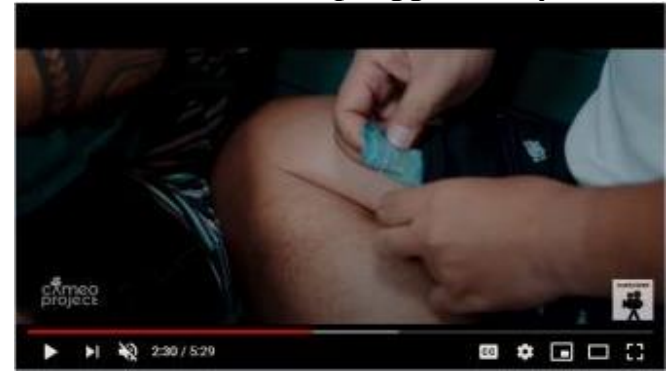

Gambar 22 Menit ke 2:30

ECU terlihat jelas pada tangan pria yang sedang merogoh uang di dalam celananya. Fokus gambar tersebut terdapat pada tangan dan aktivitas seorang pria yang sedang memegang uang. 




Gambar 23 Menit ke 2:45

Pada scene ini terlihat dari sorotan mata menakutkan dari perempuan yang memakai masker. Fokusnya terdapat pada mata perempuan tersebut yang berwarna beda dari manusia pada umumnya, dan dari tatapannya yang sangat tajam ketika melihat pria berbaju hijau garis-garis.

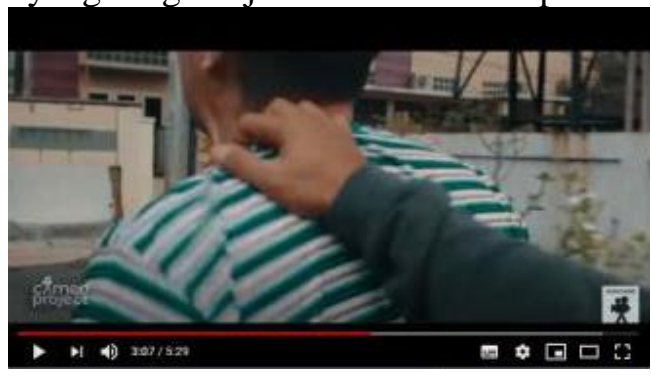

Gambar 24 Menit ke 3:07

Pada scene ini terlihat dari fokus tangan yang sedang memegang pundak pria berbaju hijau garis-garis. Tangan tersebut merupakan tangan pria berjaket biru yang ingin menegur pria berbaju hijau garis-garis karena keluar rumah tidak memakai masker.

\section{CU (Close Up)}

Close Up menampilkan bagian detail dari ujung kepala hingga leher bagian bawah, boleh memotong sedikit kepala bagian atas. Close Up juga dapat digunakan untuk mendeskripsikan suatu shot yang mengisolasi satu bagian dari tubuh misalnya, kaki atau tangan, sebagian dari sebuah objek besar misalnya keyboard laptop atau keseluruhan dari sebuah objek kecil misalnya uang (Ginanjar Angga W \& Abdillah, 2017).



Gambar 25 Menit ke 2:32

CU pada scene ini terdapat pada pria berbaju hijau garis-garis sedang melihat ke arah uang lima puluh ribu rupiah. Uang tersebut dipegang oleh pria yang memakai kaos dalam atau singlet. Gambar tersebut menunjukkan fokus tatapan mata pria berbaju hijau garis-garis ke uang lima puluh ribu.

\section{OSS (Over Shoulder Shot)}

Over Shoulder Shot adalah pengambilan gambar dari teknik belakang objek (Sandy \& Sya'dian, 2020). Pengambilan gambar di mana kamera berada di belakang bahu salah satu pelaku, dan bahu si pelaku tampak atau kelihatan dalam frame. 




Gambar 26 Menit ke 2:46

Sudut ini diambil dari bahu perempuan berbaju ungu yang terlihat sangat menakutkan. Terlihat pria berbaju hijau garis-garis lari terbirit-birit karena ketakutan melihat perempuan tersebut. Pria tersebut bergerak lari terbirit-birit terlihat dari gerakan tangannya.

\section{VWS (Very Wide Shot)}

Very Wide Shot merupakan tipe shot sangat luas, namun secara visual lebih sempit jika dibandingkan dengan tipe Extream Wide Shot (Mulyana \& Budiantoro, 2019). Dalam shot ini subjek masih terlihat, namun lingkungan sekitarnya yang lebih ditonjolkan dan dapat digunakan untuk shooting exterior maupun interior. Biasanya menampilkan dimana, kapan, dan sedikit informasi mengenai siapa.

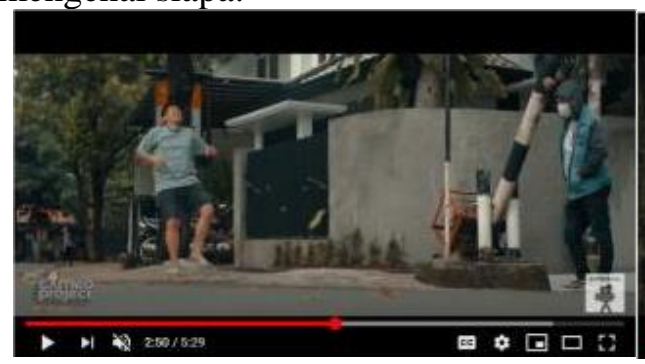

Gambar 27 Menit ke 2:50



Gambar 28 Menit ke 2:56

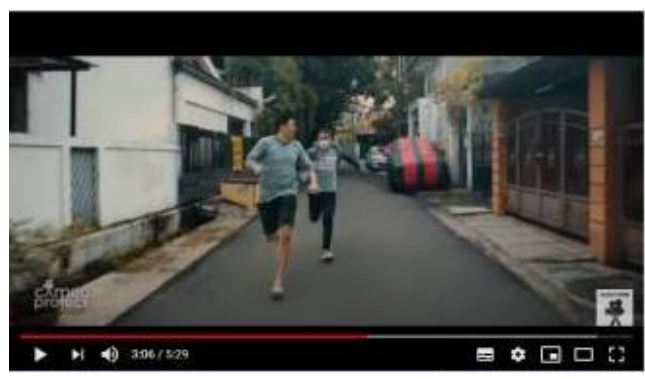

Gambar 29 Menit ke 3:06

Pada ketiga scene di atas terlihat lebih menonjolkan suasana sore hari di komplek atau perumahan yang sepi. Suasana sore terlihat pada pencahayaan yang redup kegelapan, karena ketika kedua pria tersebut berdiri dan berlari bayangan dirinya tidak terlihat.

\section{SIMPULAN}

Berawal dari adanya kasus virus corona, membuat Indonesia masuk dalam peta penyebaran virus jenis baru atau virus corona (Covid-19). Dari adanya kasus tersebut, banyak masyarakat Indonesia mengalami kepanikan. Karena, melalui pengumuman kasus tersebut dapat tersimpulkan bahwa wabah virus corona telah masuk ke Indonesia. Langkah antisipasi dan mitigasi atas pandemi virus corona itu pun bukan merupakan pilihan. Namun, sudah menjadi keharusan antisipasi bersama. Masyarakat Indonesia sebenarnya tidak perlu merasa khawatir secara berlebihan apalagi panik. Sebab, kepanikan yang berlebihan justru akan memicu tindakan irasional dan bahkan bisa membuat keadaan lebih buruk. Hasil penelitian menyatakan bahwa 
kebijakan lockdown dalam suatu wilayah yang terdampak wabah virus corona perlu dilakukan sebagai upaya meminimalisir penyebaran wabah virus tersebut. Walaupun tentunya menimbulkan dampak negatif yang beresiko, dalam pelaksanaan kebijakan lockdown ini perlu adanya kerjasama antara pemerintah dan masyarakat guna mewujudkan kesejahteraan sosial masyarakat.

\section{DAFTAR PUSTAKA}

Ali, M. (2013). Pembuatan film pendek tentang bahaya zat karsinogen dengan menggunakan view potrait berjudul "Plastic Bottles." STIKOM Surabaya, 7-28. http://repository.dinamika.ac.id/id/eprint/571/

Buana, D. R. (2020). Analisis perilaku masyarakat indonesia dalam menghadapi pandemi virus corona (covid-19) dan kiat menjaga kesejahteraan jiwa. SALAM: Jurnal Sosial dan Budaya Syar-i, 7(3), 217-226. https://doi.org/10.15408/sjsbs.v7i3.15082

Chariri, A. (2009). Landasan filsafat dan metode penelitian kualitatif. Workshop Metodologi Penelitian Kuantitatif Dan Kualitatif, Laboratorium Pengembangan Akuntansi (LPA), Fakultas Ekonomi Universitas Diponegoro Semarang, 31 Juli- 1 Agustus 2009, 1-27. http://eprints.undip.ac.id/577/

Angga W, G., Abdillah, F., \& Nurmalinda, E. (2017). Perancangan promosi wisata bahari Pantai Menganti Kebumen. Desain Komunikasi Visual, 6-27. https://doi.org/10.1017/CBO9781107415324.004

Holmes, K. V. (2003). SARS-associated coronavirus. New England Journal of Medicine, 348(20), 1948-1951.

Indrawati, W. (2020). Membantu Masyarakat mencegah wabah covid-19. ADALAH: Buletin Hukum \& Keadilan, 4(1), 145-150. https://doi.org/10.15408/adalah.v4i1.15579

Laksana, D. A. W. (2013). Video. TI-D3 UDINUS, 1-16. https://dinus.ac.id/ repository /docs/ajar/video,sudut pengambilan gambar,storyboard_file_2013-04 11_062415_ deddy_award_widya_laksana_m.pd_.pdf

Maahury, H. A., Erdiono, D., \& Sembel, A. (2015). Implementasi Micromegas Daniel Libeskind. Jurnal Arsitektur, 4(1), 175-183. https://doi.org/10.1017/CBO9781107415324.004

Mujib, M. A. (2020). Mortalitas terhadap perkembangan kasus covid - 19. https://scholar. google.co.id/scholar?hl=id\&as_sdt=0\%2C5\&q=mitasari+mortalitas+terhadap+perkemb angan+kasus+covid+-+19\&btnG=\#d=gs_qabs\&u=\%23p\%3DjDDqDqhVwEQJ

Mulyana, L. D. R., \& Budiantoro, H. (2019). Komunitas dakwah jalanan dalam film dokumenter Bidang Director of Photography. Fotografi \& Film. http://repository.unpas.ac.id/id/eprint/42827

Sandy, A. S., \& Sya'dian, T. (2020). Analisis sinematografi program edisi ada gula, ada sejahtera di DAAI TV Sumut. Mahasiswa Fakultas Seni Dan Desain, 1(1), 329-340. http://e-journal.potensi-utama.ac.id/ojs/index.php/FSD/article/view/727

Setiono, M. A., \& Riwinoto. (2015). Analisa pengaruh visual efek terhadap minat responden film pendek eyes for eyes pada bagian pengenalan cerita (part 1) dengan metode skala likert. Jurnal Komputer Terapan, 1(2), 29-36. jurnal.pcr.ac.id/index.php/jkt/article/view/55 
Syafrudin, C., \& Pujiyono, W. (2013). Pembuatan film animasi pendek "Dahsyatnya Sedekah" berbasis multimedia menggunakan teknik $2 d$ hybrid animation dengan pemanfaatan graphic. Sarjana Teknik Informatika, 1(1), 387-398. https://doi.org/10.12928/jstie.v1i1.2554

Tamamuddin, I. (2017). Pemetaan teknik sinematografi types of shots pada iklan web series axe "Axelerate the Series." Universitas Negeri Malang, 4-14. https://doi.org/10.1136/ip.2010.029629

Tarigan, A. P. (2020). Makalah penyakit menular dan virus corona. OSF Preprints, 1-13. https://scholar.google.co.id/scholar?hl=id\&as_sdt=0\%2C5\&q=amalia+putri+taigan+pe nyakit+menular+dan+virus+corona\&btnG=\#d=gs_qabs\&u=\%23p\%3DZPbnRwjd0a8J

Yunus, N. R., \& Rezki, A. (2020). Kebijakan pemberlakuan lock down sebagai antisipasi penyebaran virus corona covid-19. SALAM: Jurnal Sosial Dan Budaya Syar-I, 7(3), 227238. https://doi.org/10.15408/sjsbs.v7i3.15083 